\title{
A new learning model of software engineering in vocational education
}

\author{
Dicky Nofriansyah', Ganefri' ${ }^{2}$, Ridwan $^{3}$ \\ ${ }^{1}$ Department of Information System, STMIK Triguna Dharma, Indonesia \\ ${ }^{2,3}$ Faculty of Engineering, Universitas Negeri Padang, Indonesia
}

\begin{tabular}{l} 
Article Info \\
\hline Article history: \\
Received Jan 15, 2020 \\
Revised May 30, 2020 \\
Accepted Jul 20, 2020 \\
\hline Keywords: \\
Artificial intelligence \\
Intelligent tutoring system \\
Learning management system \\
New learning model \\
Project based learning
\end{tabular}

\section{Article Info}

Article history:

Received Jan 15, 2020

Revised May 30, 2020

Accepted Jul 20, 2020

Keywords:

Artificial intelligence

Intelligent tutoring system

New learning model

based learning

\begin{abstract}
This research focused on the development a new learning model in Vocational Education to answer the challenges of this Industrial Revolution 4.0 era. The problem identified was the lack of learning outcomes, especially subjects oriented to software engineering for information systems students in particular and other computer science seen in the phenomenon of the inability of students to produce intelligent systems. From a series of validity, practicality, and effectiveness test results, use content validity with Aiken'V and construct validity with CFA (Confirmatory Factor Analysis) states that the model resulting from this study is stated, valid, practical and effective. This study also produced a new learning model with five syntaxes, namely (1) Define Problem and Design a Plan Project, (2) Interaction with Support System, (3) Create a Project, (4) Keep control and Monitoring Project, (4) Yield and Assessment of Project. And based on the test of the validity of the syntax of this model stated goodness-of-fit or valid.
\end{abstract}

This is an open access article under the CC BY-SA license.

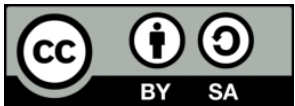

\section{Corresponding Author:}

Dicky Nofriansyah,

Department of Information System,

STMIK Triguna Dharma,

Jl. Abdul Haris Nasution, Medan, Sumatera Utara, 20122, Indonesia.

Email: dickynofriansyah@ymail.com

\section{INTRODUCTION}

The world is currently in an era of technological disruption, and digital literacy called the Industrial Revolution 4.0. One factor students must have is critical thinking [1,2]. The hallmark of this era is the extensive and structured use of information and communication technology (ICT) in aspects of human life such as social, economic and educational aspects. The process of digitization, human and computer interaction, automatic exchange of data and communication, the distortion of various human activities, and the use of information technology tools in the field of science and technology (science and technology) are characteristic in this era. In this condition, the country needs to issue strategic policies in dealing with it, including Indonesia [3].

The current government through the Ministry of Technology Research and Higher Education appealed to the leaders of higher education, especially in vocational education and training to innovate, including curriculum reconstruction. Two things were targeted in this reconstruction process including (a) giving students broader skills or competencies such as coding, big data analysis, and artificial intelligence, (b) changing the learning process face to face into blended learning and fully online learning as a new format of the learning process. Besides the learning process, there are challenges and opportunities from the development of vocational education in Indonesia, especially in the field of information and technology. There are two technical challenges, namely: (a) technological development and exponential data such as 
technical skills, analytical skills, efficiency in adopting data, coding skills, and the ability to understand information technology, and (b) fostering collaborative work such as being able to work in teams, having virtual communication skills, have skills in the field of learning media, and the ability to have cooperative skills [4].

The substance of 21st-century learning [5], three skills become the target of learning content, namely: (a) skills and innovation learning so that students have critical thinking skills, communication skills, collaborative abilities, and have creativity, (b) digital literacy skills which include literacy information, media, information and communication technology, and (c) career and life skills which include flexibility, initiative, productivity, and adaptability. Chronosystem must be able to integrate several elements, both physical, digital and biological [6]. These elements can be used as a part to strengthen the process of digital literacy, social literacy, and technological literacy. These efforts were made to provide added value and competitiveness for vocational education graduates in the industrial revolution 4.0.

The learning outcomes of a learning course become a benchmark of success of the lecturer in delivering teaching material. Form related to learning outcomes, especially those obtained from alumni and students majoring in computer science and information systems that are or have completed their final project such as a thesis. Based on the preliminary survey data, the average student who gets a good grade has the ability at level-2 (understanding) based on the Bloom's taxonomy. This is reflected due to the inability of students to analyze problems, combine related elements, encode, and develop software. Whereas it is expected that learning outcomes will be at least level 4 (analysis) up to level 6 (creations) relevant to the Indonesian National Qualification Framework which places graduates of Grade 6 graduates (an analyst). There are 2 factors that cause the ability of students at this level based on the initial identification of the problem, including (1) the factor of the substance of teaching material. Based on the above conditions, aspects of competency achieved by students at this time are only limited to aspects of knowledge such as mathematical competencies and general skills aspects such as competencies from processing data information. While other aspects of skills such as competencies in software engineering and competencies in smart systems are not achieved [7].

Based on the conditions above, innovation or efforts to synchronize the understanding of algorithms and translate them in source code are needed to improve student competency and learning ability. Some research is done by using several concepts and approaches in learning algorithms such as active learning. Based on this active learning approach, the results of learning algorithms by adopting mathematical concepts and calculus are better than other approaches [8]. In addition, in the context of how to understand the basics of computer programming can be done by several methods, including recitation methods. This recitation method is a method that makes the learner as a facilitator and gives the task to students to learn something independently and report how the results are [9]. In addition, there have been several efforts that have been made, including how to build a learning management system in learning the structure of algorithms and programming [10].

One innovation in improving the results of the learning process is the application of artificial intelligence. Utilization of artificial intelligence is expected to be able to convey information and be a solution for the application of cybersecurity. In addition, by applying artificial intelligence will provide added value from several aspects of learning, including the tutoring process, independent learning, testing, and computerized testing [11]. The problems that arise today in the midst of society and the world of education are technological disturbances in education. The problem of technological disturbances is developing so that there need to be strategies and innovative efforts that are able to answer these challenges. One of the efforts made in adopting technology and artificial intelligence in education [12].

During this time the use of information and communication technology (ICT) in the field of learning focuses on how to convey information and interactions between students and teachers such as the design of LMS (Learning Management System). The existing LMS does not apply artificial intelligence in it to optimize learning outcomes. In this study will be developed in addition to LMS as a support system to convey information, but there is also a computer-based test and machine learning in it. Computer-Based Tests are constructed to assist teachers in conducting assessments, and machine learning are used to assist in tutoring algorithm learning [13].

The current learning Intelligent Tutoring System and artificial intelligence are very much needed in learning in improving learning outcomes in this digitalization era. Intelligent Tutoring System can be interpreted as a computer application that can mimic or duplicate what humans do. In the intelligent tutoring system, there are five elements or components including the expert model, student model, instructor model and user interface [12]. Intelligent Tutoring System can be used for various activities, especially in learning. Among them are Photoshop learning [14]. Besides that, there is also learning Cryptography Data Encryption Standard (DES) with the concept of an intelligent tutoring system, and the results of this learning are $\operatorname{good}[15]$. 
Project-Based Learning Model is a construct based learning model. While based on current conditions, the theory of learning adopted is constructivism. The weakness that exists in project-based learning so far is that most students carry out instructions based on the project plan [16]. In an effort to improve the quality of learning, a lot of research and research that tries to adopt technology in this constructed model, as well as a combination of project-based learning with social media. From this research, it can be seen that there is an increase in learning outcomes from those only implementing project-based learning adopting technologies such as social media [17]. From the cognitive aspect it turns out that projectbased learning that adopts technology in learning, it turns out that the value of the experimental group and the control group that adopts CAL (Computer Assisted Learning) [18] or computer assisted test are better than those that do not implement $[18,19]$. From these 6 syntaxes of PjBL then developed to Rs-PjBL (Resource Sharing-Project Based Learning) where this model with 7 syntaxes [20]. The approach adopted in learning the industrial revolution 4.0 there are several concepts including online learning, collaboration, creativity, the theory of connectivity, and the heutagogy approach [21].

\section{RESEARCH METHOD}

The method used in this research is the research and development (R\&D) model Borg and Gall and continued experimentation. The development model in this study conducted through several stages starting from the conceptual model phase, theoretical models, then hypothetical models, and final models. The development of the model in this study is called the Project Based Learning Model into the DICKY Learning Model based on the Intelligent Tutoring System. The development method in this research refers to the R\&D stage model which Borg and Gall Model. The development research procedure above can be simplified by five main steps as shown in Figure 1. Table 1 shows the stages of the procedure for developing a DICKY Learning Model based on the Intelligent Tutoring System.

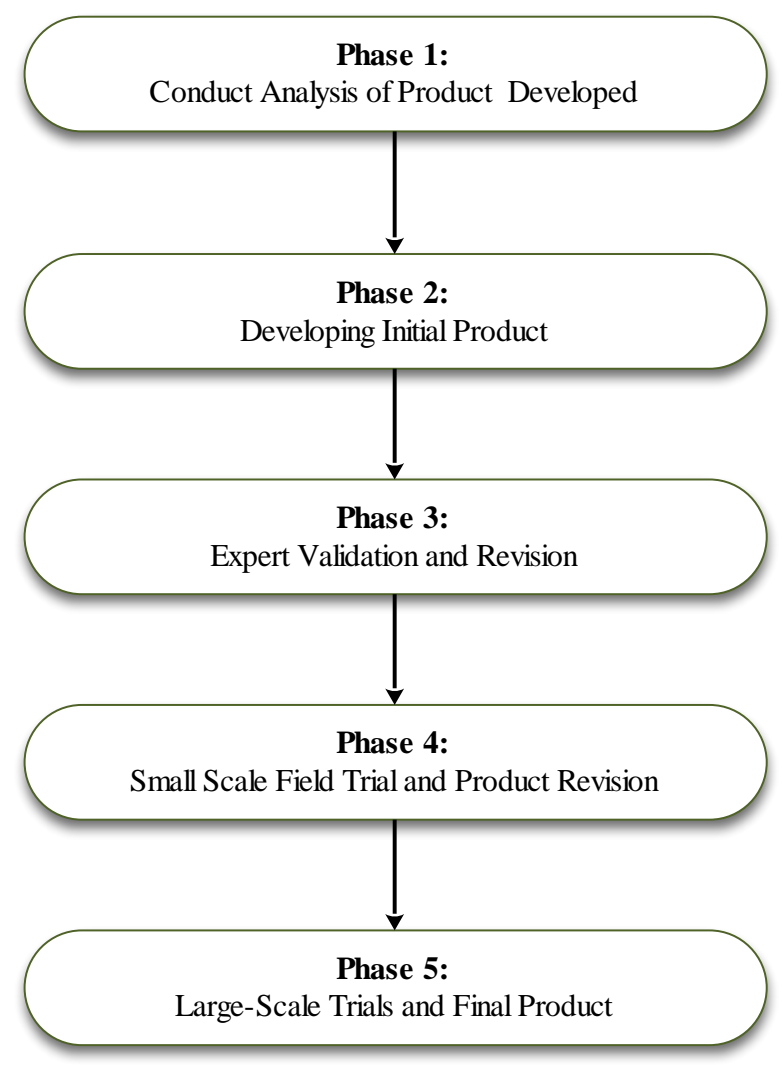

Figure 1. Phase of developing learning model 
Table 1. Acitivities of developing DICKY learning model

\begin{tabular}{|c|c|}
\hline Phases & Activities \\
\hline $\begin{array}{l}\text { Conduct Analysis of } \\
\text { Products developed }\end{array}$ & $\begin{array}{l}\text { In Phase I (Analysis) in this Development Procedure, there are several things done, } \\
\text { including problem analysis, needs analysis (both in terms of learning and software } \\
\text { design in supporting the learning process). And }\end{array}$ \\
\hline $\begin{array}{l}\text { Developing Initial } \\
\text { Products }\end{array}$ & $\begin{array}{l}\text { In Phase II, the development of learning is affiliated with the system design on the } \\
\text { development of learning devices. }\end{array}$ \\
\hline & $\begin{array}{l}\text { At this stage, namely the validation by experts of the product being developed. The } \\
\text { details of the activities carried out in stages are: a. FGD (Focus Group Discussion): is a } \\
\text { focus group discussion where scientific discussion is used for several things, namely: } 1 \text {. } \\
\text { digging in-depth information about the initial product developed in the form of the } \\
\text { DICKY Model and learning tools, } 2 \text {. developing research hypotheses, 3. collecting data }\end{array}$ \\
\hline $\begin{array}{l}\text { Expert Validation } \\
\text { and Revision }\end{array}$ & $\begin{array}{l}\text { needed to develop products in the form of constructive suggestions and criticisms. The } \\
\text { number of experts and validators is } 6 \text { in each phase consisting of professors and experts } \\
\text { in the field of Vocational and others. There are many criteria used in validating the } \\
\text { construct of learning model syntax. For Syntax } 1 \text { there are } 8 \text { evaluation criteria, Syntax } 2 \\
\text { there are } 12 \text { evaluation criteria, Syntax } 3 \text { there are } 11 \text { evaluation criteria, Syntax } 4 \text { there } \\
\text { are } 10 \text { evaluation criteria, and Syntax } 5 \text { there are } 8 \text { evaluation criteria. All indicators are } \\
\text { processed using the concept of Confirmantory Factor Analysis (CFA). }\end{array}$ \\
\hline & $\begin{array}{l}\text { At this stage, the initial testing and integration are done. The activity carried out is small- } \\
\text { scale initial testing involving research subjects and integrating learning products at }\end{array}$ \\
\hline $\begin{array}{l}\text { Small Scale Field } \\
\text { Trials and Product } \\
\text { Revisions }\end{array}$ & $\begin{array}{l}\text { www.learningmcda.com. The pre-test is to provide a preliminary test to see the cognitive } \\
\text { value of software engineering students in understanding a method in a decision support } \\
\text { system. In addition, at this stage, the validity, practicality and effectiveness of the } \\
\text { DICKY Learning Model based on the Intelligent Tutoring System with a statistical } \\
\text { approach. The number of samples in this phase are } 21 \text { students majoring in Software and } \\
\text { Informatics Engineering. }\end{array}$ \\
\hline $\begin{array}{l}\text { Large-scale Trials } \\
\text { and Final Products }\end{array}$ & $\begin{array}{l}\text { There are several things done at this stage, namely: the final evaluation after a large- } \\
\text { scale trial and the dissemination phase. The number of samples in this phase were } 32 \\
\text { students majoring in Informatics Engineering which were divided into } 2 \text { classes namely } \\
\text { control and experiment classes. The control class is a class that adopts a Project Based } \\
\text { Learning model while the Experiment Class is a class that adopts the DICKY Learning } \\
\text { model. At this stage, the final evaluation is carried out by conducting a Focus Group } \\
\text { Discussion before the product produced will be disseminated. The product that has been } \\
\text { evaluated is the result of research and development of the DICKY Learning Model based } \\
\text { on the Intelligent Tutoring System. }\end{array}$ \\
\hline
\end{tabular}

\section{RESULTS AND DISCUSSION}

\subsection{Rationality}

Vocational or vocational technology education is identified as education that prepares learners to be able to work. New challenges in the world of vocational technology education or vocational are related to supporting facilities and infrastructure. The abilities and skills that must be achieved by university graduates, especially informatics, have been regulated [7]. One of the efforts that are expected is to increase the level of learning ability from level 2 to level 3 to 6 according to the strategy based on taxonomy bloom.

\subsection{Philosopy}

The DICKY Learning Model is a development of the Resource Sharing Model - Blended Project Based Learning $[20,22]$. In that study, it was seen that there was a combination of classroom learning and the use of computer technology. In the industrial revolution era, of course, technological devices such as smartphones and the Mobile Instant Messaging (MIM) application and other social media are used as learning media [23-25]. Not only learning media, but the industrial revolution 4.0 also resulted in a change from the previous learning concept of Pedagogy and Andragogy to Heutagogy [26]. Heutagogy is an approach that requires learning for self-direct learning by utilizing material that is in the learning media [27]. In this DICKY model, the nature of heutagogy will be seen in Syntax 2, namely Interaction with support System. In this syntax, it involves the process of importing all information and instructions for implementing learning, especially in the field of software engineering. Self-direct learning can also be a solution to increase learner creativity in understanding the material being taught [28].

In Ontology Aspect, DICKY learning model is a learning model that adopts an artificial intelligence approach to the theory of learning connectivity. In the Epistemological Aspect, the DICKY learning model is a learning model that puts forward the concept of renewing the existing model, namely project-based learning and RS-BPL into a new model. And in the aspect of axiology, the DICKY learning model is a combination of learning theory, learning media, and previous learning models. From these three aspects and based on testing the validity of using Confirmatory Factor Analysis and other tests, the DICKY Learning Model is a new learning model, especially in the field of software engineering. 


\subsection{Syntax}

Based on the rationale and theoretical foundation that supports the DICKY model based on the Intelligent Tutoring System, a new learning model is developed that integrates Project-Based Learning and Intelligent Tutoring System. The basis for thinking DICKY models based on Intelligent Tutoring System is referring to several factors, namely: 1) Bloom's Taxonomy, 2) Previous Learning Models (Project-Based Learning, Resource Project-Based Learning and Blended Learning, 3) Interactivity, and 4) Learning style and 5) Development of ICT on Education [29].

Some indicators of cognitive learning are: emphasizing the ways a person uses his mind to learn, remember, and use the knowledge that has been obtained and stored in his mind effectively. In essence, verbal or visual learning that underlies observations that involve all the senses saves a longer impression and creates a sensation that leaves an imprint on students. In constructivism learning where the indicators are the reconstruction of knowledge, the discovery process, student-centred, the existence of social interaction and reflection. Social media attitude is one of important thing in vocational education student [30]. The following is a comparison or comparative study between the syntax of Project Based Learning, Blended Learning and the syntax of the DICKY Model based on the Intelligent Tutoring System as shown in Table 2.

Table 2 clearly show the visible syntax comparisons of both the Project-Based Learning model, the Project-Based Learning Model and the DICKY Model based on the Intelligent Tutoring System. The following is the development concept of the previous model so that the DICKY model based on the Intelligent Tutoring System is formed, as shown in the Figure 2. Figure 3 shows the elaboration between the learning model and the learning media. The following is the development concept of the previous model so that the DICKY Learning Model based on the Intelligent Tutoring System is formed, as shown in Figure 3.

Table 2. Comparative study of model syntax

\begin{tabular}{|c|c|c|}
\hline Project-Based Learning Model & $\begin{array}{c}\text { Resource Sharing - Blended Project Based } \\
\text { Learning Model }\end{array}$ & $\begin{array}{l}\text { The DICKY's Learning Model based on } \\
\text { the Intelligent Tutoring System. }\end{array}$ \\
\hline 1. Start with the essential question & $\begin{array}{c}\text { 1. Analysis of Need Assessment Teacher } \\
\text { and Learner }\end{array}$ & 1. Define Problem and Design a plan Project \\
\hline 3. Create a schedule & 3. Design and Development of Software & 3. Create a Project \\
\hline 4. Monitoring & 4. Development of system & 4. Keep Control and Monitoring Project \\
\hline 5. Assest the Outcome & 5. Project Assistance and Training & 5. Yield and Assessment Project \\
\hline & 7. Assessment of outcome & \\
\hline
\end{tabular}
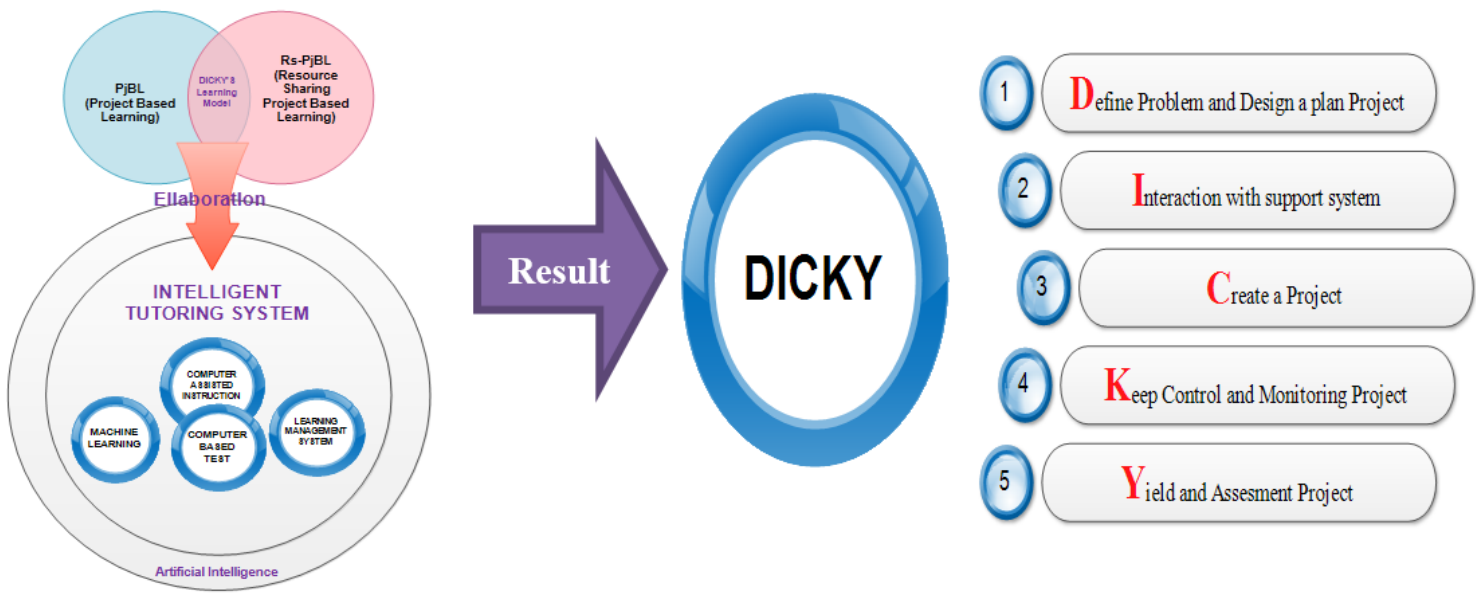

Figure 2. Ellaboration of learning model, learning media and DICKY's syntaxes

\section{Syntax 1: Define problem and design a plan project}

In this syntax, there are a number of things to do on the concept of this new learning model, namely: (1) Lecturer: Provide information to each student how the mechanism in the learning process of the course and (2) Lecturers and Students: Based on the description of the information above, students are asked to design Project plans either manually or using software such as Microsoft Projects that are based on the objectives of building a system. 


\section{Syntax 2: Interaction support system}

In this syntax, the pattern of interaction that is carried out is related to the use of ITS (Intelligent Tutoring System) in terms of implementing learning, namely. (1) Students visit this ITS and (2) Student: Finding information about material and using ITS as tools to self-direct learning.

\section{Syntax 3: Creating a project}

In this syntax, this is to actualize all aspects of the elements of syntax 1 and syntax 2 to creating project software.

\section{Syntax 4: Keep control and monitoring project}

In this syntax, an initial evaluation and stepping stone for enterprise project development in accordance with predetermined Project plans.

\section{Syntax 5: Yield and assessment of project}

In the syntax of this learning model, there are a number of things done including the student submitting the Project results to the lecturer after a final test is conducted on the previous syntax then the lecturer conducts a final evaluation to provide a final assessment of the results achieved by the student.

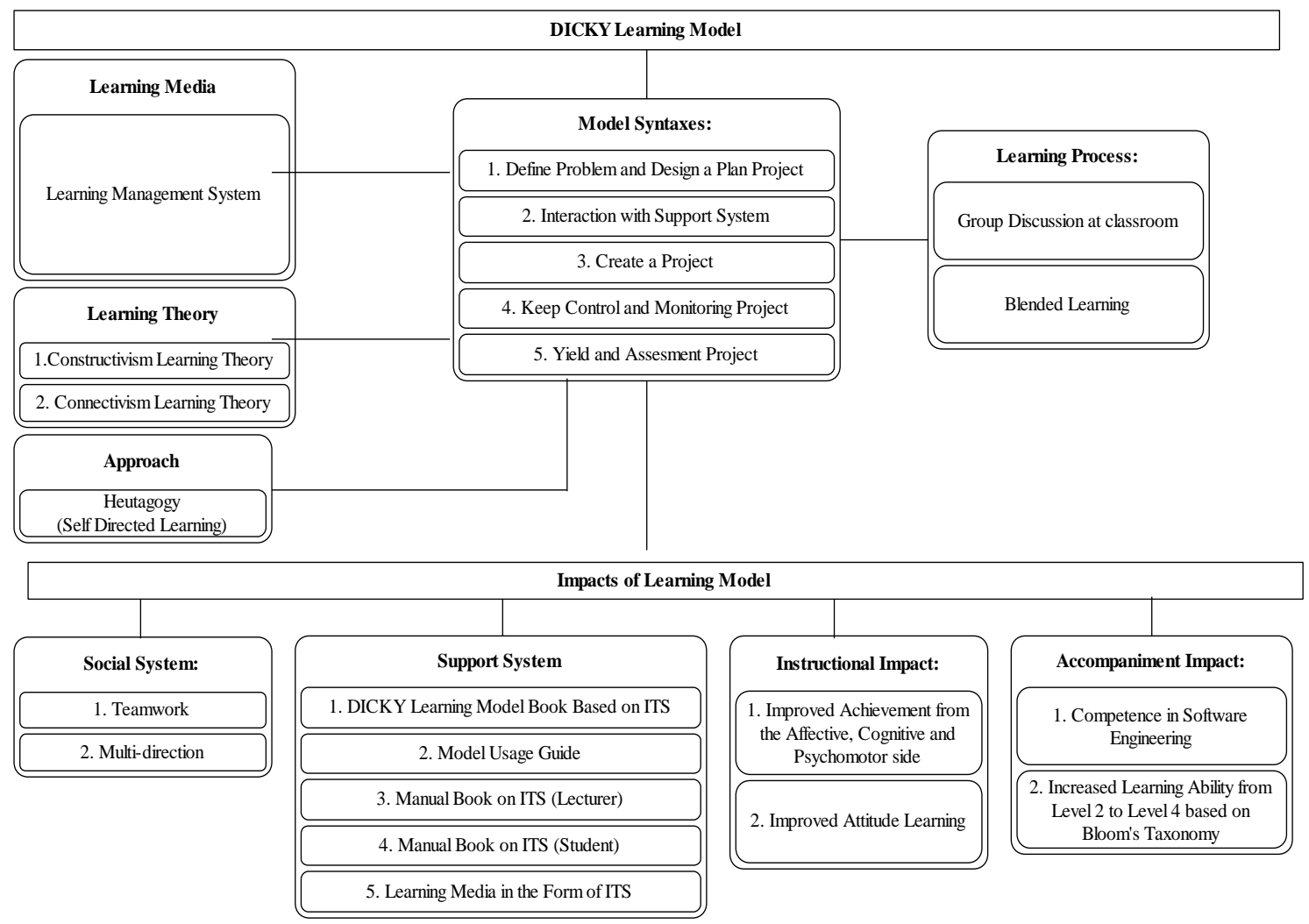

Figure 3. Theoritic of DICKY learning model

\subsection{Validation of the DICKY learning model based on intelligent tutoring system}

After conducting a Focus Group Discussion, a research and data search was conducted to test whether the DICKY learning model based on the Intelligent Tutoring System was made valid or invalid. The following is a picture of the construct validation of Syntax I to Syntax V from the DICKY learning model based on the Intelligent Tutoring System which is seen in Figure 4 to Figure 8. A model that is declared fit or in other words goodness-of-fit models must meet several aspects of assessment, namely: (a) Chi-Square is not significant (or close to zero), (b) The value of The P-Value must be more than 0.05 (> 0.05), (c) the value of the RSMEA (Root Mean Square Error of Approximation) must be less than 0.05 $(<0.05)$ [31]. Figure 4 to Figure 8 state the value of RSMEA $=0.000$. Based on the analysis of the data in Figure 4 to Figure 8 confirm that the construct validity values can be grouped or classified as valid or fit. 


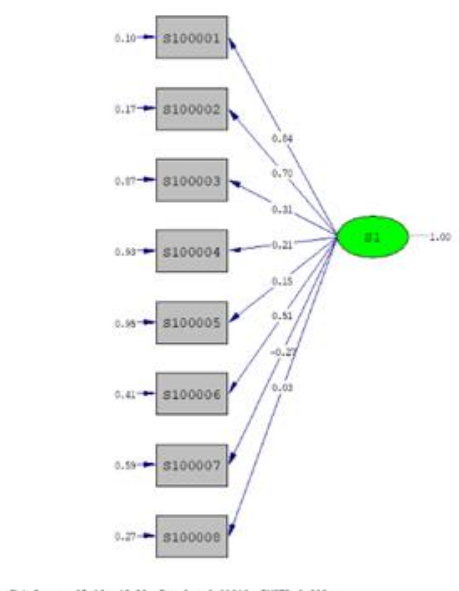

Figure 4. CFA of syntax I

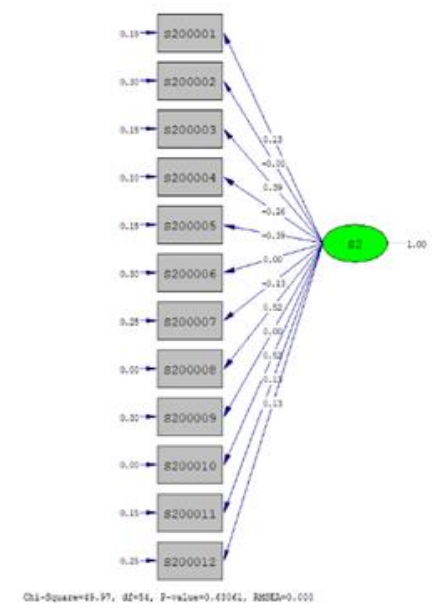

Figure 5. CFA of syntax II

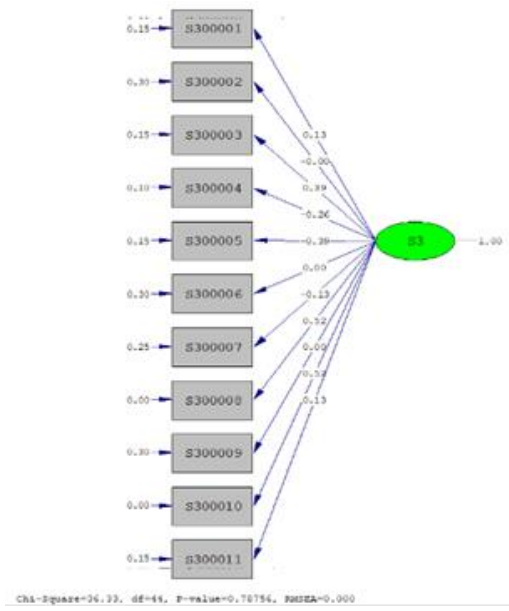

Figure 6. CFA of syntax III

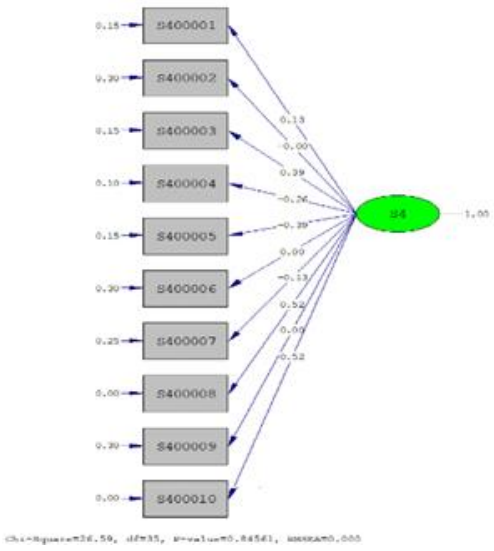

Figure 7. CFA of syntax IV

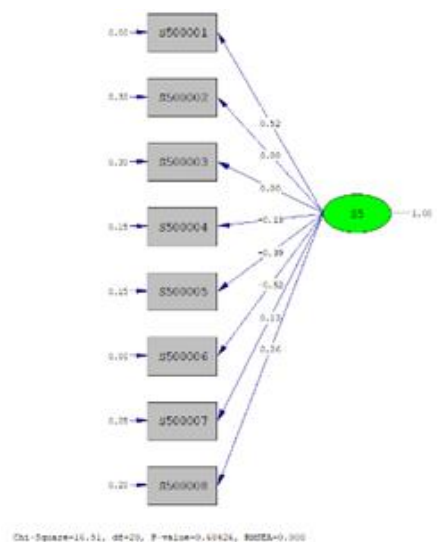

Figure 8. CFA of syntax V

\subsection{Practicality test from DICKY learning model based on intelligent tutoring system}

In measuring the practicality of the DICKY Learning Model Based on Intelligent Tutoring System in terms of various aspects is shown in Table 3.

Table 3. Summary of test practicality of DICKY learning model based on intelligent tutoring system

\begin{tabular}{ccccc}
\hline \multirow{2}{*}{ No } & \multirow{2}{*}{ Evaluator } & Indicator I & $\begin{array}{c}\text { Assessment of Indicator } \\
\text { Indicator II }\end{array}$ & Indicator III \\
\hline 1 & Evaluator I & 5 & 5 & 5 \\
2 & Evaluator II & 5 & 3 & 4 \\
3 & Evaluator III & 4 & 4 & 4 \\
4 & Evaluator IV & 4 & 5 & 5 \\
5 & Evaluator V & 5 & 5 & 5 \\
& Grand Total & 24 & 23 & 22 \\
& Average & 4.8 & 4.6 & 4.4 \\
& Percentage (\%) & $96 \%$ & $92 \%$ & $88 \%$ \\
& $*$ Note & Very practical & Very practical & Very practical \\
\hline
\end{tabular}

\subsection{Efectiveness test}

\subsubsection{Limited effectiveness test}

After measuring and testing the results of the validity of the model and other products, then doing a limited trial of both the pre-test and post-test processes, the step that must be done is to test the effectiveness. Based on the results of data analysis of the limited trial classes conducted in the previous 
phase, the gain score value can be obtained between pre-test and post-test classes. The following are the results of the analysis of the pre-test and post-test data and the gain score as shown in Table 4. Figure 9 shows a visualization of the difference in the average value of the pre-test and post-test can be seen in the histogram. Based on Figure 9, it can be seen differences in learning outcomes between pre-test and post-test classes of courses in decision support systems. Thus, it can be stated and concluded that the treatment or treatment of the DICKY Learning Model that adopts the Intelligent Tutoring System is more effective to improve learning outcomes.

Table 4. Post-test analysis results from limited trial class data

\begin{tabular}{cccccccc}
\hline Respondents & Pre-Test & Post-Test & Gap & Respondents & Pretest & Post & Gap \\
\hline 1 & 65 & 70 & 5 & 12 & 50 & 70 & 20 \\
2 & 70 & 80 & 10 & 13 & 70 & 80 & 10 \\
3 & 55 & 90 & 35 & 14 & 40 & 70 & 30 \\
4 & 40 & 90 & 50 & 15 & 50 & 85 & 35 \\
5 & 35 & 60 & 25 & 16 & 50 & 85 & 35 \\
6 & 60 & 80 & 20 & 17 & 30 & 90 & 60 \\
7 & 70 & 80 & 10 & 18 & 40 & 80 & 40 \\
8 & 50 & 90 & 40 & 19 & 40 & 95 & 55 \\
9 & 40 & 95 & 55 & 20 & 45 & 80 & 35 \\
10 & 40 & 85 & 45 & 21 & 50 & 80 & 30 \\
11 & 70 & 70 & 0 & & & & \\
Total & 1060 & 1705 & 645 & & & & \\
Average & 50.48 & 81.19 & 30.71 & & & &
\end{tabular}

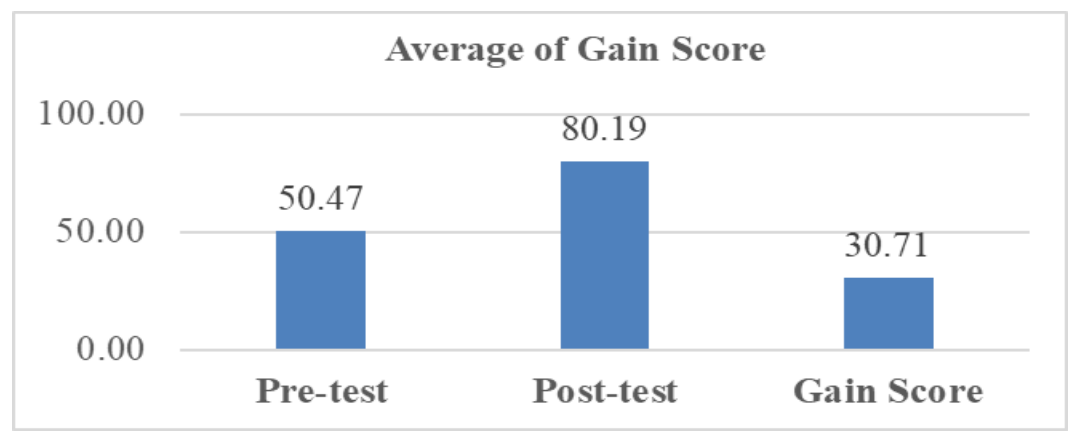

Figure 9. Post-test histogram of limited trial class data

\subsubsection{Expanded effectiveness test}

Table 5 shows the comparison results between the control class and the experimental class based on the pre-test and post-test values. Based on the data description presented both, the DICKY learning model based on Intelligent Tutoring System is effective to improve student learning outcomes.

Table 5. Results of improvement of student learning outcomes between the control class and the experimental class

\begin{tabular}{cccc}
\hline No & Value & Control Class & Experimental Class \\
\hline 1 & Pre-test & 60.313 & 61.093 \\
2 & Post-test & 74.219 & 79.687 \\
Gain Score & & 13.906 & 18.594 \\
\hline
\end{tabular}

\subsection{Test requirements from analysis}

\subsubsection{Normality test}

The normality test process is carried out with several approaches and rules. In this study, the Shapiro Wilk statistical approach was used with a significance level of 0.05; it is shown in Table 6 and Table 7. Based on Table 6 and Table 7, can be seen above with the Shapiro Wilk approach, the significance value is 0.463 , which means it is greater than 0.05 . It means that the learning outcomes of the data have a normal distribution. 
Table 6. Pre-test results improved student learning outcomes

\begin{tabular}{cccccccc}
\hline \multirow{2}{*}{ Class } & \multicolumn{2}{c}{ Kolmogorov-Smirnov } & \multicolumn{4}{c}{ Shapiro-Wilk } \\
& & Statistic & Df & Sig. & Statistic & Df & Sig. \\
\hline \multirow{2}{*}{ Value } & Control & .219 & 32 & .200 & .835 & .32 & .463 \\
& Experimental & .228 & 32 & .200 & .833 & .32 & .423 \\
\hline
\end{tabular}

Table 7. Post-test results improved student learning outcomes

\begin{tabular}{cccccccc}
\hline \multirow{2}{*}{ Class } & \multicolumn{2}{c}{ Kolmogorov-Smirnov } & \multicolumn{3}{c}{ Shapiro-Wilk } \\
& & Statistic & Df & Sig. & Statistic & Df & Sig. \\
\hline \multirow{2}{*}{ Value } & Control & .222 & 32 & .203 & .855 & .32 & .445 \\
& Experimental & .168 & 32 & .122 & .928 & .32 & .414 \\
\hline
\end{tabular}

\subsubsection{Homogeneity test}

Homogeneity testing or testing process of a study is conducted to find out whether some indicators or variances of each data sample or population are declared homogeneous or not. The following are the homogeneity test results from the Pre-Test values for both the control and experiment classes, presented in the Table 8 and Table 9. Based on Table 8 and Table 9, it shows the significant value of the pre-test value both from the control class and the experimental class that is 0.128 and 0.165 , which means it is greater than 0.05 . Based on these results, it shows that the variance of the population data is homogeneous and can be used for further testing.

Table 8 . Homogeneity test of pretest values in both control and experiment classes

\begin{tabular}{cccc}
\hline $\begin{array}{c}\text { Levene } \\
\text { Statistic }\end{array}$ & Df1 & Df2 & Sig. \\
\hline 2.376 & 1 & 62 & .128 \\
\hline
\end{tabular}

Table 9. Homogeneity test of post-test values in both control and experiment classes

\begin{tabular}{cccc}
\hline $\begin{array}{c}\text { Levene } \\
\text { Statistic }\end{array}$ & Df1 & Df2 & Sig. \\
\hline 6.280 & 1 & 62 & .165 \\
\hline
\end{tabular}

\subsubsection{T-Test}

The different test processes of the pre-test results from both the control class and the experimental class can be seen from Table 10 and Table 11. Based on Table 10 and Table 11, it shows the Asymp value. Sig. (2-tailed) which is 0.010 .

Table 10. T-Test from pre-test results of control and experiment classes

\begin{tabular}{ccccc}
\hline & Class & $\mathrm{N}$ & Mean Rank & Sum of Ranks \\
\hline \multirow{4}{*}{ Value } & Pre-test (Control Class) & 32 & 21.47 & 687.00 \\
& Pre-test (Experimental Class) & 32 & 43.53 & 1393.00 \\
Total & 64 & & \\
& Mann-Whitney U & 159.000 & & \\
Wilcoxon W & 687.000 & & \\
Z & -4.910 & & \\
& Asymp.Sig. (2-tailed) & .000 & & \\
\hline
\end{tabular}

Table 11. T-Test from post-test results of control and experiment classes

\begin{tabular}{ccccc}
\hline & Class & $\mathrm{N}$ & Mean Rank & Sum of Ranks \\
\hline \multirow{3}{*}{ Value } & Post-test (Control Class) & 32 & 21.47 & 687.00 \\
& Post-test (Experimental Class) & 32 & 43.53 & 1393.00 \\
Total & 64 & & \\
& Mann-Whitney U & 325.500 & & \\
Wilcoxon W & 853.500 & & \\
Z & -2.573 & & \\
& .010 & & \\
Asymp.Sig. (2-tailed) & &
\end{tabular}

\section{Analysis of learning outcomes from affective perspectives}

Table 12 shows differences in learning outcomes in the affective domain. Table 12 informs the results or the average value based on affective values both in the control class, with an average value of 78.595 while the experimental class psychomotor average value is 82.345 . 
Table 12. Differences in learning outcomes in the affective domain

\begin{tabular}{cccccc}
\hline No & Assessment Aspects & Control Class & $\begin{array}{c}\text { Experimental } \\
\text { Class }\end{array}$ & $\begin{array}{c}\text { Affective Score } \\
\text { Differences }\end{array}$ & Percentage $(\%)$ \\
\hline 1 & Discipline & 72.5 & 84.38 & 11.88 & 14.08 \\
2 & Commitment & 80 & 82.5 & 2.5 & 2.96 \\
3 & Responsible & 81.25 & 85 & 3.75 & 4.44 \\
4 & Communication & 76.25 & 81.25 & 5 & 5.93 \\
5 & Confidence & 79.38 & 79.38 & 0 & 0.00 \\
6 & Interest to learn & 75 & 86.25 & 11.25 & -6.67 \\
7 & Critical & 85.63 & 80 & -5.63 & 1.48 \\
8 & Creative & 78.75 & 80 & 1.25 & 30 \\
\end{tabular}

\section{Analysis of learning outcomes from a psychomotor perspective}

From the psychomotor aspect, 2 things are measured, namely: (1) Project Software Work Flow and (2) Competency Test Results. Based on the two instruments the following is an explanation as shown in Table 13. Based on the Table 13, shows the results or the average value based on psychomotor values both in the control class with an average value of 80.08 while in the experimental class, the average psychomotor value is 85.78 .

Table 13. Result of learning outcome from a psychomotor perspective

\begin{tabular}{|c|c|c|c|c|c|c|c|c|c|}
\hline Respondent & Control & Experimental & Improve & $\%$ & Respondent & Control & Experimental & Improve & $\%$ \\
\hline 1 & 77.5 & 82.5 & 5 & 6.061 & 17 & 82.5 & 82.5 & 0 & 0.000 \\
\hline 3 & 82.5 & 87.5 & 5 & 5.714 & 19 & 82.5 & 90 & 7.5 & 8.333 \\
\hline 5 & 80 & 82.5 & 2.5 & 3.030 & 21 & 82.5 & 82.5 & 0 & 0.000 \\
\hline 6 & 72.5 & 80 & 7.5 & 9.375 & 22 & 82.5 & 87.5 & 5 & 5.714 \\
\hline 7 & 72.5 & 92.5 & 20 & 21.622 & 23 & 82.5 & 82.5 & 0 & 0.000 \\
\hline 10 & 77.5 & 92.5 & 15 & 16.216 & 26 & 82.5 & 87.5 & 5 & 5.714 \\
\hline 11 & 77.5 & 82.5 & 5 & 6.061 & 27 & 82.5 & 90 & 7.5 & 8.333 \\
\hline 12 & 82.5 & 85 & 2.5 & 2.941 & 28 & 80 & 85 & 5 & 5.882 \\
\hline 13 & 82.5 & 92.5 & 10 & 10.811 & 29 & 82.5 & 82.5 & 0 & 0.000 \\
\hline 14 & 82.5 & 87.5 & 5 & 5.714 & 30 & 82.5 & 90 & 7.5 & 8.333 \\
\hline
\end{tabular}

\section{CONCLUSION}

After conducting the research, there are conclusions from this study: (a) Based on the results of testing the validity of the DICKY Learning Model, it is declared valid based on several aspects of validity both from the aspect of content validity and the construct that adopts Aiken'V and Confirmatory Factor Analysis. (b) Based on the results of practicality testing of related elements in the DICKY Learning model which consists of practicality test results is declared "Very Practical". (c) Based on the results of testing the effectiveness associated with the control class and the experimental class, DICKY Learning Model can be declared effective based on the t-test (limited test).

\section{ACKNOWLEDGEMENTS}

We are very grateful to Faculty of Engineering, Universitas Negeri Padang for all support in completing this research.

\section{REFERENCES}

[1] T. M. T. Nguyễn and T. T. L. Nguyễn, "Influence of explicit higher-order thinking skills instruction on students' learning of linguistics," Think. Ski. Creat., vol. 26, no. 3, pp. 113-127, Dec 2017.

[2] S. Y. Özelçi and G. Çalışkan, "What is critical thinking? A longitudinal study with teacher candidates," International Journal of Evaluation and Research in Education (IJERE), vol. 8, no. 3, pp. 495-509, 2019. 
[3] M. Abud, Indonesia: New Digital Nation? Internews Center for Innovation and Learning, 2012. [Online]. Available: https://internews.org/resource/indonesia-new-digital-nation

[4] M. Hermann, et al., "Design Principles for Industrie 4.0 Scenarios," in 2016 49th Hawaiian International Conference on Systems Science, Koloa, pp. 3928-3937, 2016. [Online]. Available: 10.1109/HICSS.2016.488

[5] O. S. Oluwatumbi, "Ict Literacy Among Vocational and Technical Education Teachers in Kogi State Technical and Vocational Colleges: Skill Gaps," Br. J. Educ., vol. 3, no. 5, pp. 21-30, 2015.

[6] B. Trilling and C. Fadel, 21 st century skills: learning for life in our times. John Wiley \& Sons 2009.

[7] Perpres Nomor 8, "KKNI Aptikom 2016," pp. 1-5, 2016.

[8] K. Kalkulus and M. Kharis, "Improving Student Understanding through Active Learning by Developing Algorithms and Language Ideas from Concepts and Principles (in Bahasa)," Kreano, Jurnal Matematika KreatifInovatif, vol. 2, no. 2, pp. 143-151, 2011.

[9] T. R. Murniasih, T. Fayeldi, J. S. Supriadi, and N. Malang, "Recitation Methods to Improve Conceptual Understanding in Basics Computer Programming," Jurnal Edukasi, vol. 4, no. 1, pp. 8-12, 2017.

[10] L. S. Muchlis, "Development of the DIVA Learning Management System Model in Algorithms and Programming Courses (in Bahasa)," Disertasi: Universitas Negeri Padang, 2018.

[11] J. J. Lu and L. Harris, "Artificial Intelligence (AI) and Education," Congressional Research Service, In Focus, IF10937, 2018. [Online]. Available: https://crsreports.congress.gov/search/\#/?termsToSearch=Artificial\% 20Intelligence\%20(AI)\%20and\%20Education\&orderBy=Relevance

[12] J. Jauhari and M. Ibrahim, "Intelligent Tutoring System as an Innovative Effort in Learning for Computer Assisted Learning (in Bahasa)," J. Generic, vol. 5, no. 2, pp. 1-5, 2010.

[13] Doreen Holtsch, Silja Rohr-Mentele, Eva Wenger, Franz Eberle, and Richard J. Shavelson " Challenges of a crossnational computer-based test adaptation," Empir. Res. Vocat. Educ. Train., vol. 8, no.18, pp. 1-32, 2016.

[14] M. Z. Shaath, et al., "Photoshop (CS6) intelligent tutoring system," International Journal of Academic Research and Development, vol. 2, no. 1, pp. 81-86, 2017.

[15] A. E. A. Elnajjar and S. S. A. Naser, "DSE-Tutor: An intelligent tutoring system for teaching DES information security Algorithm," International Journal of Advanced Research and Development, vol. 2, no. 1, pp. 69-73, 2017.

[16] S. E. Nayono and Nuryadin, "Development Module of Project Based Learning Learning (in Bahasa)," J. Pendidik. Teknol. dan Kejuru., vol. 21, no. 1, pp. 340-347, 2013.

[17] M. Makky and O. C. Chatib, "Development of Project Based Learning Methods for Internet Based and Social Media (in Bahasa)," Seminar Nasional Pengembangan Pendidikan Tinggi, Padang, vol. 5, no. 1, pp. 105-111, 2016.

[18] N. Stozhko, "Interdisciplinary project-based learning: technology for improving student cognition.," Res. Learn. Technol., vol. 23, no. 1063519, pp. 1-13, 2015.

[19] A. Z. Abidin, E. Istiyono, N. Fadilah, W. Sunu, and B. Dwandaru, "A computerized adaptive test for measuring the physics critical thinking skills," Evaluation \& Research in Education, vol. 8, no. 3, pp. 376-383, 2019.

[20] Wahyudi, Resource Sharing-Blended Project Base Learning: Sistem Operasi Android, Linux, dan Mac OS. Leutikaprio, 2017.

[21] Theresia Widyantini, "Application of Project Based Learning Model in Class VII Number Pattern Material (in Bahasa)," PPPPTK Mat., vol. 4, no.1, pp. 1-19, 2014.

[22] Wahyudi, Resource Sharing - Blended Project Based Learning (RS-BPBL). Leutikaprio, 2016.

[23] S. So, "Mobile instant messaging support for teaching and learning in higher education," Internet High. Educ., vol. 31, no. 2, pp. 32-42, 2016

[24] L. A. Abdillah, "Exploring Student'S Blended Learning Through Social Media," ComTech, vol. 7, no. 4, pp. 245-254, 2016.

[25] L. Abdillah, "Enriching Information Technology Course Materials by Using Youtube," E-Proceeding 5Th Int. Conf. Artif. Intell. Comput. Sci. Inf. Technol. 2017, no. July, pp. 75-82, 2017.

[26] K. Hoque, A. Z. Razak, and M. Zohora, "Service delivery in higher education (HE): A comparative study between public and private universities," Life Sci. J., vol. 10, no. 3, pp. 108-117, 2013.

[27] A. Glassner and S. Back, Introduction-Heutagogy: What Does It Mean and Why It Is Needed - Exploring Heutagogy in Higher Education. Springer, Singapore, pp. 1-8, 2020.

[28] N. Arsyad, et al., "Developing a self-learning model based on open-ended questions to increase the students' creativity in calculus," Global Journal of Engineering Education, vol. 9, no. 2, pp. 143-147, 2017.

[29] C. Chinien and B. Kotsik, "The Use of ICTs in Technical and Vocational Education and Training," p. $190,2017$.

[30] E. P. Yildiz, M. Çengel, and A. Ayşe, "Social media attitudes among vocational school students," International Journal of Evaluation and Research in Education (IJERE), vol. 8, no. 3, pp. 384-391, 2019.

[31] R. M. Mueller, M. J. Lambert, and G. M. Burlingame, "Construct Validity of the Outcome Questionnaire: A Confirmatory Factor Analysis," J. Pers. Assess., vol. 70, no. 2, pp. 248-262, 1998. 